\title{
Between Nordism and Nationalism: The Methods of the Norden Associations' Educational Efforts, 1919-1965
}

\author{
Henrik Åström Elmersjö
}

\begin{abstract}
The Norden Associations (föreningarna Norden) were established in 1919 with the intention of promoting understanding and cooperation between the Nordic countries. The definition of "Norden" was negotiated from the very beginning, and Icelandic and Finnish associations were not established until the 1920s. Promoting understanding and cooperation was very much considered an educational effort, and Norden was imagined within educational efforts sponsored by the associations. In this regard, the associations had predecessors in the Nordic schoolteacher meetings that dated back to the age of Scandinavism in the middle of the nineteenth century. The Norden Associations created special school boards in the 1920s in order to both promote a more Nordic approach in some subjects - mainly language, geography, and history-and to promote cooperation between the countries, with the youth as the catalyst for a more Nordistic future. This article looks into how the Norden Associations imagined a Nordic school, in which a Nordic sentiment was established, and how this imagination related to the reality of the nationalistic school and to ideas of broader international cooperation, between which the "Nordic idea" has always been sandwiched. The article shows how the methods used effectively hindered the imagination of Norden and the "Nordic idea" beyond the scope of cooperation between nations.
\end{abstract}

Keywords • nationalism, Norden Association, interwar era, post-war era, international education

\section{Introduction}

The construction of "Norden" as a cultural unit goes back a long way and has been linked to transformations of European concepts of unity and division. ${ }^{1}$ From a Western European perspective, an earlier partition between the "barbaric" Northern Europe and the "civilised" Southern Europe transformed into a "barbaric" Eastern Europe and a "civilised" Western Europe in the eighteenth century. In this context, the Nordic countries could be seen as a periphery, separated from the Slavic east and the Germanic middle of Europe. After the Napoleonic Wars, "Norden" started to take shape as a cultural entity, beginning with the newly established union between Norway and Sweden, and eventually also incorporating Denmark, Iceland, and Finland. ${ }^{2}$

1 In this construction "Norden" usually means the Nordic countries of Denmark, Finland, Iceland, Norway, and Sweden including their respective realms and including the more-and sometimes less—autonomous entities such as the Faroe Islands, Greenland, Sápmi, and Åland.

2 Max Engman and Åke Sandström, "Det nya Norden," in Det nya Norden efter Napoleon, ed. Max Engman and Åke Sandström (Stockholm: Stockholm University, 2004), 16-18; Uffe Østergaard, "Norden - europæisk eller nordisk?" Den jyske Historiker 69-70 (1994), 18; Øystein Sørensen and Bo Stråth, "Introduction: The Cultural Construction of Norden," in The Cultural Construction of

Henrik Åström Elmersjö is Associate Professor of History and Education at the Department of Education, Umeå University, Sweden.

Email: henrik.astrom.elmersjo@umu.se 
Ideas of Norden and "Nordicness" (nordiskhet) was especially prevalent after World War One, and in the midst of nationalist hegemony economic and cultural cooperation was mostly forwarded, as opposed to a new pan-nordic nationalism. ${ }^{3}$ Education was an arena that was deemed especially interesting, in line with new expectations on the youth of the time. ${ }^{4}$

In this article I aim to analyse the way international non-governmental organisations in the Nordic setting-the Norden Associations-envisioned and utilised education as an arena for creating, recreating, and negotiating Nordic identity and cultural cohesion among Nordic youth. I also intend to show how this vision was amended to fit into the nationalistic as well as the international and global sentiment of the interwar period and in what way that changed in the post-war era. I will especially scrutinise the methods used to convey the message, more so than the ideas themselves. The main research question is: how was Norden methodically imagined, re-created, and negotiated in the associations' educational efforts? I will also relate my findings to earlier research regarding the Nordic teacher meetings during the nineteenth century.

\section{Theoretical considerations}

In order to get at how the imagination and negotiation of Norden is embedded in the methods utilised to spread the idea of Nordicness through education I will borrow theoretical assumptions from the sociology of scientific knowledge. The concept methodological nationalism is a theoretical notion that is mostly utilised in discussions about research within the humanities and the social sciences. ${ }^{5}$ This notion clarifies how the nation is re-enacted and reproduced in research through the framing of different studies in national contexts that are not problematised. By enclosing research questions in a national setting, the nation-state becomes the terminal unit of inquiry, thus re-establishing the nation itself as an entity. In this study I intend to utilise parts of this concept, discussing nationalistic influences on methods employed by international organisations empirically. The national outlook of international organisations in the interwar period will therefore be analysed in much the same way as, for example, historiographical research would analyse historians taking the nation for granted in past historical research. This approach will also enable an analysis of potential shifts towards the creation of more "Nordic" methods.

The term "methodological nationalism" was originally coined in the 1970s and then applied in different sociological contexts, mostly when evaluating research in

Norden, ed. Øystein Sørensen and Bo Stråth (Oslo: Scandinavian University Press, 1997), 20. See also Henrik Åström Elmersjö, Norden, nationen och historien: Perspektiv på föreningarna Nordens historieläroboksrevision 1919-1972 (Lund: Nordic Academic Press, 2013), 47-52.

3 Monika Janfelt, Att leva i den bästa av världar: Föreningarna Nordens syn på Norden 1919-1933 (Stockholm: Carlssons, 2004), 26-28; Kari Haarder Ekman, "Mitt hems gränser vidgades:" En studie $i$ den kulturella skandinavismen under 1800-talet (Göteborg: Makadam, 2010); Ruth Hemstad, Fra Indian summer til nordisk vinter: Skandinavisk samarbeid, skandinavisme og unioinsuppløsningen (Oslo: Akademisk publicering, 2008).

4 Henrik Berggren, Seklets ungdom: Retorik, politik och modernitet 1900-1939 (Stockholm: Tidens förlag 1995).

5 See e.g., Andreas Wimmer and Nina Glick Schiller, "Methodological Nationalism and Beyond: Nation-state Building, Migration, and the Social Sciences," Global Networks 2, no. 4 (2002), 301-34. 
the social sciences. ${ }^{6}$ Wimmer and Glick-Schiller break down methodological nationalism into three very much interrelated modes, the first being ignoring the nationalist forms of inclusion and exclusion as key features of the modern condition. This ignorance is showcased in making the national condition of modern societies invisible. By not paying attention to how inclusion and exclusion based on national conceptions have formed modern society, the national conception becomes a given, and the nation-state is re-imagined and re-enacted without any attention being paid to it. ${ }^{7}$

A second mode of methodological nationalism is taking the national frame for granted, naturalising it without any problematisation of the national discourses, histories, or loyalties behind it. This is perhaps the most fundamental mode of methodological nationalism. National frames and entities are taken for granted not only within national societies and in the political arena, but in research and in international cooperation, too. Researchers and even so-called international foundations or societies seldom reflect upon the national framework of community.

The third mode discussed by Wimmer and Glick-Schiller is the territorialisation of the imagination. Paraphrasing Giddens, they conclude that "the web of social life was spun within the container of the national society, and everything extending over its borders was cut off analytically [...]."

By employing the concept of methodological nationalism in an analysis of an international project, I hope to be able to find key features of the negotiation regarding the local, the regional, the national, the Nordic, the European, and the global in educational efforts aimed to manoeuvre between these levels in the way that the Norden Associations' work was envisioned. Although there are obvious differences between Nordism and nationalism, not least regarding how implemented the concepts were regarding the organisation of everyday life in the timespan I am researching, they nevertheless are similar ideological concepts — and "imagined communities" — that might be analysed utilising similar concepts. In light of these theoretical considerations, the questions become; how do ignorance, taking for granted, and territorialisation, fit when moving from the national to the Nordic? How did the Norden Associations' methods regarding educational efforts relate to ideas of the nation and ideas of Norden?

\section{Sources}

The Norden Associations' have large open archives in Denmark, Finland, Norway, and Sweden, and much of their activities are described in minutes from meetings and other texts deposited in these archives. I have mostly used the Swedish archive

6 See e.g., Herminio Martins, "Time and Theory in Sociology," in Approaches to Sociology: An Introduction to Major Trends in British Sociology, ed. John Rex (London: Routledge, 1974), 276; Anthony D. Smith, Nationalism in the Twentieth Century (Oxford: Martin Robertson, 1979), 191; Ulrich Beck, "The Cosmopolitan Society and its Enemies," Theory, Culture \& Society 19, no. 1-2 (2002), 21. The concept is also related to Michael Billig's concept of "banal nationalism;" Michael Billig, Banal Nationalism (London: Routledge, 1995).

7 Wimmer and Glick Schiller (2002), 304.

8 Ibid., 307.

9 Benedict Andersson, Imagined Communities: Reflections on the Origin and Spread of Nationalism (London: Verso, 1983). 
for this article, but a great deal of the documents filed in the archive are copies of documents filed in the other Norden Associations' archives. It is therefore possible to map more than just the Swedish association's activity without exploring all the archives. ${ }^{10}$ However, some resources from the Norwegian archive and some contemporary printed material published by the Norden Associations (Mainly Nordens kalender and Nordisk tidskrift) have also been utilised in this analysis.

I have also employed earlier research regarding the Nordic teacher meetings and other research on the connectedness of educational ideas and practices between different contexts in northern Europe. Much of this research shows how ideas conceptualised as Nordic were manifested in discourses regarding education long before the Norden Associations started their activities, which makes this research useful for the purposes of this article.

\section{Nordism in the beginning of the twentieth century}

There are weak but clear connections between the Nordism of the twentieth century and the Scandinavism of the nineteenth century. Proponents of Scandinavism coveted a political union between Denmark, Norway and Sweden, while the more modern Nordism grew out of a conceived need for cooperation between small, independent states during and after World War One. Even if Scandinavism had a renaissance at the very beginning of the twentieth century, the dissolution of the union between Norway and Sweden basically put an end to the idea of a political union between the Scandinavian countries. ${ }^{11}$ The project of Nordism also tended to be a balancing act between national and Nordic identity in a similar manner as the pacifist movements in the interwar period had to balance their internationalism with patriotism. ${ }^{12}$

However, there are many different "Norden" discourses, and they are in diverse ways related to nationalism, international cooperation, and even the white-supremacy movement. Within the conceptualisation of Nordism, there has been a tendency to see "Norden" as a semi-national identity marker, between the European and the national. The Nordic nationalisms also have some common traits, with a focus on the historical figure of "the free peasantry" as a symbol for the national heritage being perhaps the most common. ${ }^{13}$ However, the idea of a Nordic heritage is in many ways as much a downplay of the Baltic and European components of the five nations' histories and nature as it is a celebration of the geographical, historical and political fellowship between them. ${ }^{14}$

10 The archive is in a process of moving from the Swedish National Archives (Riksarkivet) to the TAMarchives in Stockholm, and the placement of the sources might therefore change.

11 Østergaard (1994), 15-19; Janelt (2004), 26-28; Ekman (2010); Hemstad (2008).

12 See Ingela Nilsson, Nationalism i fredens tjänst: Svenska skolornas fredsförening, fredsfostran och historieundervisning 1919-1939 (Umeå: Umeå University, 2015); Mona Siegel, The Moral Disarmament of France: Education, Pacifism, and Patriotism, 1919-1940 (New York: Cambridge University Press, 2004); Sandi E. Cooper, Patriotic Pacifism: Waging War on War in Europe, 18151914 (New York: Oxford University, 1991); Jan Kolasa, International Intellectual Cooperation: The League Experience and the Beginnings of UNESCO (Wrocław: Polskiej Akademii, 1962).

13 Henrik Stenius, "Nordic Associational Life in a European and an Inter-Nordic Perspective," in Nordic Associations in a European Perspective, ed. Risto Alapuro and Henrik Stenius (Baden-Baden: Nomos, 2010), 37-40; Nils Kayser Nielsen, Bonde, stat og hjem: Nordisk demokrati og nationalismfra pietismen til 2. verdenskrig (Aarhus: Aarhus universitetsforlag, 2009), 19; Østergaard (1994), 9.

14 See for example Uffe Østergaard, “The History of Europe Seen from the North,” European Review 14, 
The content of a proposed Nordic heritage has been negotiated on different levels. Danish, Norwegian, and Swedish cooperation was more profound at the start of the interwar period. Finland was not seen as a totally unproblematic Nordic country given its very different language and different (recent) history. ${ }^{15}$ However, Finland filled an important role in the Nordic community by making the boundary between Norden and Russia more distinct. Both in Finland and in Norway there was also a problematic history of dependency on Denmark and Sweden that further fuelled suspicion towards Nordic cooperation at a very nationalistic time. Focusing on the Nordic heritage in Finland could be interpreted as a focus on the Swedish heritage at a time when Finland was just winning its independence. ${ }^{16}$ From a Swedish point of view, there might also have been a quest for bringing Finland into the Nordic context in order to make sure that the connection between Finland and Sweden was maintained and that Finland was not brought, or pushed, in a Baltic direction. ${ }^{17}$

The Icelandic Nordicness was perhaps less questioned. However, Iceland had similar problems with the establishment of vivid cultural and political connections to Denmark and Norway, something that could be seen as a re-conquering of Iceland at a time when it was also winning its independence. ${ }^{18}$ During the interwar period, Nordists settled on a definition of Norden with boundaries towards the rest of the world drawn at the southern border of Denmark and the eastern border of Finland, demarking Norden as something other than the power of central Europe and the "uncivilised" Russia. ${ }^{19}$

\section{The Norden Associations}

The Norden Associations (föreningarna Norden) were formed in this context in Denmark, Norway, and Sweden in 1919, in Iceland in 1922, and in Finland in 1924. During World War One, ideas for a Nordic union or federal state were voiced, and conservatives who wanted a more moderate mode of cooperation envisioned a public association for Nordic cooperation with members from all the states that were deemed Nordic. This would mean that a single association with members from all Nordic countries should be formed.

In 1918, a configuration with one association in each of the countries, that is, one Danish, one Norwegian, and one Swedish association started to be projected instead (this configuration also became a reality in 1919). Committees where formed in Denmark, Norway, and Sweden to lay the foundation on which the associations could be formed and to enunciate what their agenda would be. The committee least interested in the more far-reaching models of cooperation, the Norwegian committee,

no 2 (2006), 288; Bo Stråth, "The Swedish Image of Europe as the Other," in Europe and the Other and Europe as the Other, ed. Bo Stråth (Brussels: Peter Lang, 2000).

15 Max Engman, "Är Finland ett nordiskt land?” Den jyske Historiker 69-70 (1994), 62-63.

16 Uffe Østergaard, “The Geopolitics of Nordic Identity: From Composite States to Nation States," in The Cultural Construction of Norden, ed. Øystein Sørensen and Bo Stråth (Oslo: Scandinavian University Press, 1997), 44.

17 Jan A. Andersson, Nordiskt samarbete: Aktörer, idéer och organisering 1919-1953 (Lund: Lund University, 1994).

18 Vagn Wåhlin, “Island, Færøerne, Grønland og det nordiske," Den jyske Historiker 69-70 (1994), $42-43$.

19 Janfelt (2005), 231-32. 
set the agenda by not wanting to be a part of any associational model that had a political union on its programme. The steps taken seem to indicate an effort to unite nationalism and Nordism by accepting what were considered to be distinctive differences between the Nordic nations, and at the same time highlighting some common ground. ${ }^{20}$

Norwegian worries about Swedish subversion against Norwegian independence were not entirely unjustified. In the Swedish debate regarding League of Nations-membership, it was quite clear that Swedish nationalists and conservatives branded Norden as a Swedish domain..$^{21}$ All of the associations were formed by elites (academics, politicians, and industrialists) and it would not be until World War Two that members would be recruited on a large scale from all walks of life. In a way, Nordism in the interwar period might have been part of a larger ideological and cultural (male) bourgeois movement.

Federalist ideas arose again during World War Two, but settled back on the cultural cooperation that was already established..$^{22}$ The height of the Nordistic sentiment was perhaps reached during the 1960s, before Denmark entered the European Economic Community, and a new interest in European identity and cooperation was established in Norden. ${ }^{23}$

\section{The Norden Associations' educational ideas, activities, and organisation}

Already by the beginning of the twentieth century international networks were established within different sciences, the peace movement, and between advocates for professional collaboration on an international stage. In a lot of ways this interest for what was happening in other countries was coupled with both nationalist hegemony and a disciplinarisation process, which also influenced teachers and the educational sciences. ${ }^{24}$ When discussing education and internationalisation, especially in the context of (international) non-governmental organisations ((I)NGOs) and other interest groups acting independently from official national or local governments, the interwar period (1919-1939) has been deemed a very important period. ${ }^{25}$ After World

20 Monika Janfelt, "Föreningarna Norden mellan nordism och nationalism," in Mångkulturalitet och folkligt samarbete, ed. Krister Ståhlberg, Nord 2000:29 (Copenhagen: Nordisk Ministerråd, 2000), 30. See also Christopher S. Browning and Pertti Joenniemi, "From Fratricide to Security Community: Re-Theorising Difference in the Constitution of Nordic Peace," Journal of International Relations and Development 16 (2013), 483-513.

21 Torbjörn Norman, "Ansiktet mot öster: Svensk nationalism mot Nationernas förbund," in Väst möter Öst: Norden och Ryssland genom historien, ed. Max Engman (Stockholm: Carlssons, 1996), $215-18$.

22 Andersson (1994), 59; Janfelt (2005), 68-76. See also Jan Hecker-Stampehl, Vereinigte Staaten des Nordens: Integrationsideen in Nordeuropa im Zweiten Weltkrieg (München: Oldenburg, 2011).

23 Lars Hovbakke Sørensen, "Norden som idé og praksis: Den danske Foreningen Nordens rolle som politisk-ideologisk pressionsgruppe 1940-1960," Historie, no. 1 (1996), 90-100. See also Svein Olav Hansen, "Foreningerne Norden 1919-1994: Ambisjoner og virklighet," Den jyske Historiker 69-70 (1994), 124.

24 Eckhardt Fuchs, "Educational Sciences, Morality and Politics: International Educational Congresses in the Early Twentieth Century," Paedagogica Historica 40, no. 5-6, (2004), 757-84.

25 John Boli and George M. Thomas, "INGOs and the Organization of World Culture," in Constructing World Culture: International Non-Governmental Organizations since 1875, ed. John Boli and George M. Thomas (Palo Alto: Stanford University Press, 1999); Akira Iriye, Global Community: The Role of International Organizations in the Making of the Contemporary World (Berkeley: University of California Press, 2002); Eckhardt Fuchs, "The Creation of New International Networks in Education: 
War One a supranational organisation was also founded (the League of Nations) beginning to take international cooperation to a more official level. After World War Two the supranational organisations like Unesco and the Council of Europe took over much of the role of influencing national educational systems in a much more efficient way than had been the case for the League of Nations, even if educational efforts had also been on the agenda for the League. ${ }^{26}$ However, there were also important predecessors on the Nordic scene interested in education.

\section{Arenas for educational Nordism predating the Norden Associations}

More or less organised Nordic cooperation on the educational scene started already in the nineteenth century. Norway and Sweden were in a union, which encompassed a common monarch and a common foreign and trade policy. Even though school policy was not the same in Norway and Sweden, Merethe Roos have shown that a shared textual culture - that is, public arenas of expression with common normsregarding schooling formed in the middle of the nineteenth century, especially regarding the connection between the Church and the schools. ${ }^{27}$

In the beginning of the 1860s, initiatives were taken to establish Nordic teacher meetings. Previous research has concluded that the teacher meetings were a consequence of Scandinavism and the rapid development of the elementary school (folkskola) in the Nordic countries. A meeting in Copenhagen was planned for 1864, but was cancelled due to the Second Schleswig War. ${ }^{28}$ This war also dampened the interest in Scandinavism, but the idea of cultural exchange continued, and the interest for teacher meetings was sustained with the first meeting instead held in Gothenburg in 1870.

These meetings then continued for 100 years, and changed focus multiple times, but in the nineteenth century they were both an arena for the exchange of pedagogical ideas and an arena for the imagination of Norden, perhaps more in the wake of political Scandinavism, heading in the direction of cultural Nordism. ${ }^{29}$ According to Håkan Andersson, who has looked into the topics discussed at these meetings up until 1910, they can be characterised as more or less international pedagogical subjects, not really related to Norden or the idea of Nordic culture. The meetings could

The League of Nations and Educational Organizations in the 1920s," Paedagogica Historica 43, no. 2 (2007). See also Henrik Åström Elmersjö, “The Norden Associations and International Efforts to Change History Education, 1919-1970: International Organisations, Education, and Hegemonic Nationalism," Paedagogica Historica 51, no. 6 (2015), 727-43.

26 See e.g. Fuchs (2007); Thomas Nygren, "UNESCO and Council of Europe Guidelines, and History Education in Sweden, c. 1960-2002," Education Inquiry 2, no. 1 (2011), 37-60; Poul Duedahl, "Selling Mankind: UNESCO and the Invention of Global History," Journal of World History 22, no. 1 (2011); Romain Faure, Netzwerke der Kulturdiplomatie: Die Internationale Schulbuchrevision in Europa, 1945-1989 (Berlin: Walter de Gruyter, 2015). See also B. J. Elliott, "The League of Nations Union and History Teaching in England: A Study in Benevolent Bias," History of Education 6, no. 2 (1977); Susannah Wright, "Creating Liberal-Internationalists World Citizens: League of Nations Union Junior Branches in English Secondary Schools, 1919-1939.” Paedagogica Historica 56, no. 3 (2020).

27 Merethe Roos, ”Tidlige skoleforbindelser: Svensk-norsk idéutveksling på skolens område rundt midten av det 19. århundre og dannelsen av tekstkulturer over kjølen," Nordic Journal of Educational History 5, no. 1 (2018), 3-25.

28 Johan Backholm, "När lärarna blev nordister: Om skandinavism och nordism på de första nordiska skolmötena," Nordisk tidskrift no. 6 (1994), 17-27.

29 Ibid. 
then be described as an arena for the Nordenisation of the pedagogical culture, rather than as an arena for the dissemination of cultural Nordism. By creating a Nordic arena for the discussion of pedagogical ideas and concepts, the pedagogical culture in some sense broke the national barrier in the same way as the shared textual culture had already done. ${ }^{30}$ However, the meetings seems to have been more about the organisational structure of something Nordic than about launching ideas about Nordic identity in schools. In relation to an on-going pedagogical modernisation, these meetings have been described as somewhat restrained; a willingness to change the world through pedagogy might have been there, but those were only to be moderate changes. ${ }^{31}$

The Nordic teacher meetings were not an isolated manifestation of Nordic ideas on the organisational level. They were preceded by Nordic student meetings (18291875), the Scandinavian natural sciences meetings (1839-1936), and the Nordic Church meetings (1857-1861). However, these meetings ended in the nineteenth century or in the interwar period, but the teacher meetings continued. ${ }^{32}$ During the period between 1870 and World War One, there was also a vibrant "Nordic School Youth Movement" that organised the exchange of ideas between Nordic school youth, where strong links were established between pupil organisations in the Nordic countries. ${ }^{33}$

\section{The interwar period}

The overall "working programme" (arbetsprogram) that the Swedish Norden Association launched in 1919 focused on "deepening the knowledge about Danish and Norwegian conditions in various fields." ${ }^{4}$ In the associations' joint membership journal Nordens kalender, a text about the relationship between the Nordic and the national tried to pinpoint what the "national" meant in a Nordic context: "Our own national feelings will only grow more pure and real if they develop a feature of Nordic affinity." 35 The Norwegian minister of foreign affairs, Halvdan Koht, wrote in the same journal a few years later regarding his work as a minister:

For Norway it might sometimes be natural to cooperate with Sweden and Finland, other times with Denmark or Iceland. [...] Each of the countries could always have special interests they need to protect. But most of the time it will have an advantage in standing together with one or more of the other [Nordic countries]. ${ }^{36}$

30 Håkan Andersson, "Skola och lärare i nordismens tjänst: De nordiska skolmötena 1870-1910," in Utbildningshistoria 1989, ed. Urban Dahlöf, Årsböcker i svensk undervisningshistoria 163 (Uppsala: Föreningen för svensk undervisningshistoria, 1989); Roos (2018).

31 Joakim Landahl, "Det nordiska skolmötet som utbildningspolitisk arena (1870-1970): Ett rumsligt perspektiv på den moderna pedagogikens historia," Utbildning \& Demokrati 24, no. 3 (2015), 9.

32 Backholm (1994), 18.

33 Björn Norlin, “The Nordic Secondary School Youth Movement: Pupil Exchange in the Era of Educational Modernization, 1870-1914," in Beyond the Classroom: Studies on Pupils and Informal Schooling Processes in Modern Europe, ed. Anna Larsson and Björn Norlin (Frankfurt am Main: Peter Lang, 2014), 83-102.

34 The programme committee's proposal for a working programme, A:1, Archive of the Swedish Norden Association (ASNA), Swedish National Archives (SNA), 3 (my translation).

35 Nordens kalender 1934, 2 (my translation).

36 Halvdan Koht, "Nordisk samarbeid ut-etter," Nordens kalender 1936, 9 (my translation). 
These two statements showcase the nationalistic base for the kind of Nordic ideas that the associations demonstrated in the interwar period. This also had repercussions for their work in the educational field.

Almost immediately upon their inauguration, the Norden Associations turned to schools and education in order to get their message of Nordic cultural cooperation across to the youth. Of course, they could utilise the teachers' interest in Nordic cooperation underlined by - among other things - the Nordic teacher meetings. The Norden Associations initiated school committees within each association. A manifesto on how the associations were to approach questions related to schools was issued, and the associations tied what they saw as important "school people" to their cause. ${ }^{37}$ This might not have been a hard task in the interwar period. International work that did not challenge the commitment to the nation state was often seen as a way to commit to both of the hegemonic ideas of the time-international peace and national prosperity. ${ }^{38}$

School trips were one strategy used by the associations' school committees for the dispersion of Nordicness to Nordic school children. Summer courses for school children that would lead to meetings between children from the different Nordic countries were also on the agenda, as well as different types of financial support for other organisations that worked with internordic meetings and issues, for example, the scouts. ${ }^{39}$ In a way these organised meetings took over some of the organisational features of the "Nordic School Youth Movement" that had previously organised similar events for pupils, by pupils. ${ }^{40}$

One way of spreading knowledge about the other countries was through the teaching of each other's languages. Lecturers in the neighbouring countries' languages were therefore sponsored in order to make sure that college and university students in the Nordic countries could study each other's languages. ${ }^{41}$ Language lecturers sent to foreign countries during the interwar period were a way to transfer knowledge, not only about the language itself, but also about more general cultural ideas regarding the lecturers' countries of origin. Through these lecturers, the nationalistic sentiment-visible in domestic literary teaching — was transferred to other countries as a way of imagining the nation and exporting the nationalistic image. ${ }^{42}$

The associations also had a strong commitment to the textbooks used in Nordic schools, mostly the history textbooks, and launched a limited survey of the textbooks in the 1920s and a mutual almost total survey in 1932-1935. After World War

37 Föreningen Norden och det nordiska samarbetet (Stockholm: Föreningen Norden, 1928), 63-69. See also Janfelt (2005), 82-85.

38 Wright (2020), 4. See also Erez Manela, The Wilsonian Moment: Self-Determination and the International Origins of Anticolonial Nationalism (Oxford: Oxford University Press, 2007).

39 See e.g. Minutes from the Swedish Association's board meeting, January 10, 1920, A1:1, ASNA, SNA, $\$ 7$; Minutes from the Swedish Association's school committee meeting, October 26, 1925, A1:2, ASNA, SNA, 1-3; Minutes from the Swedish Association's board meeting, November 18, 1932, ASNA, SNA, §5; Norden: Förening i Finland för nordiskt samarbete 1924-1934 (Helsinki: Föreningen Norden, 1934), 48.

40 Norlin (2014), 99-100.

41 Norden: Förening i Finland för nordiskt samarbete 1924-1934 (Helskinki: Föreningen Norden, 1934), 24.

42 See e.g., Andreas Åkerlund, "Ambassadors of the Swedish Nation: National Images in the Teaching of the Swedish Lecturers in Germany 1918-1945," Paedagogica Historica 51, no. 5 (2015), 595-613. 
Two, this mutual textbook revision was made continuous with national commissions of experts overseeing the textbook production in the Nordic states. ${ }^{43}$

Most attention in the interwar period was given to the teachers in elementary school, who were seen as the associations' apostles. ${ }^{44}$ In relation to the work with textbooks, one of the members of the Norwegian commission of experts in the history textbook revision commented that "the history teacher means more than the history textbook [for the diffusion of Nordic sentiment]." ${ }^{45}$ Courses for teachers and exchange programmes were initiated by the school committees, and these venues seemingly functioned as arenas for the dispersal of ideas about Norden directed towards the teachers in the Nordic countries. However, as with the Nordic teacher meetings in the nineteenth century, less attention was given to the Nordic idea, and more to the meetings themselves, with hopes of learning about each other:

Regarding the youth, the [Swedish school-] committee reckon that summer courses should be held in a Swedish town, where conditions are favourable, with school children from one other Nordic country, with an agenda in accordance with the courses for German children in Sweden, that was successfully realised last summer [... ${ }^{46}$

In this case, emphasis is clearly on how to organise the summer courses, and nothing is said about the ideas that are to be conveyed. It is even compared to courses held for children outside the sphere of Nordic cooperation and affinity. The courses for German children (not organised by the Norden Association) — which was to be copied-was most likely general courses about Swedish culture and language, and not about Nordic cooperation and affinity. The emphasis on having children from only one other Nordic country probably directed the proposed courses towards bilateral information on national culture and language, rather than towards any Nordic idea or sentiment.

A lot of attention was focused on informing pupils in Nordic schools about the other Nordic countries, and the teachers were given the role of mediator. However, in the interwar period there was some concern regarding the teachers' own ability to present a true representation of the other Nordic countries. One early example of this was the Norwegian association's commitment to lend 50 diapositive slides and a complete written lecture about Norway to schools in Stockholm. The idea was that the Swedish teachers could "use this lecture when showing the pictures." 47 An image of Norway would be transmitted in a complete package where Norwegians wrote about Norway, and Swedish teachers were only the medium to convey a pre-written

43 The textbook revision has been discussed elsewhere: Elmersjö (2013); (2015); Henrik Åström Elmersjö, "Negotiating Norden: Nordic Historians Revising History Textbooks, 1920-1970," in Making Nordic Historiography: Connections, Tensions \& Methodology, 1850-1970, ed. Pertti Haapala, Marja Jalava and Simon Larsson (New York: Berghahn Books, 2017).

44 Janfelt (2005), 85.

45 Memorandum on Danish Textbooks by Haakon Vigander, August 15, 1932, vol. 194, Archive of the Norwegian Norden Association (ANNA), Norwegian National Archives (NNA), 6 (my translation, original emphasis).

46 Minutes from the Swedish Association's school committee meeting, October 26, 1925, A1:2, ASNA, SNA, 2 (my translation, original emphasis). See also minutes from the Swedish Association's board meeting, January 10, 1920, A1:1, ASNA, SNA, \$8; Minutes from the Swedish Association’s board meeting, May 20, 1930, ASNA, SNA, \$9; Minutes from the Swedish Association's board meeting, November 18, 1932, ASNA, SNA, \$6.

47 “P.M. ang. Skolesaker," November 2, 1921, vol. 193, ANNA, NNA, 7 (my translation). 
message. The imagination of the Nordic was limited to the imagination of the different countries that made up the region.

The methods utilised in the efforts of the Norden Association directed at schools were more or less imbued with nationalist thought, and not with Nordism. Nothing in the organisation of the associations' activities seems to be rooted in any idea starting with a common Nordic viewpoint. Instead, activities seem to start in the differences, in learning about each other as something different. This led towards an imagination of Norden limited in territorial and cultural scope. Nordicness was not imagined as an idea separate from the nations; it was imagined as the sum of the nations.

Territorialisation was definitely a part of this imagination, not seeing the entire region as one, but as a puzzle made up of five territorial pieces, which meant that no strings of the cultural web were really allowed to cross the border. Students were not supposed to learn about a common social web, but more about the webs of the other Nordic countries.

However, it seems that most of the imaginations of Norden was nationalised by taking the nation for granted, by not evoking a common Nordicness as the starting point for cooperation, and by not even trying to establish this common viewpoint. Even if the inclusion and exclusion within the national framework was not discussed at all, it would still be wrong to say that the Norden Associations ignored the nation as an important entity. On the contrary, the associations' texts showcase an awareness of the nation, with the associations themselves being made up mostly of conservative nationalists in the interwar period. However, the question of how to build a Nordic sentiment if the nation is always taken as the point of departure never seems to have been asked. Instead, the Nordic sentiment was built in a way directly linking it to-and departing from-five different national sentiments.

In short, the Norden Associations imagined a Nordic school as five national schools where pupils learned a lot about the other Nordic countries.

\section{The post-war period}

The way the associations were rooted in the hegemonic nationalism of the interwar period was commented upon after World War Two by the associations themselves. Even though delegates from the five associations' boards met each year ("the delegates' meeting"), the lack of a truly inter-Nordic arena for the members of the Norden Associations was obvious almost immediately after the war. In an effort to regain some credibility in the debate over internationalism in the wake of European cooperation, and also to develop more official Nordic cooperation within the inter-parliamentary Nordic Council (Nordiska rådet), which was established in 1952, the Nordic Congress was founded and had its first meeting in Oslo in $1954 .{ }^{48}$ This established a more inter-nordic arena for the Norden Associations, where also educational matters could be discussed.

The reorganisation of the associations continued with the formation of a common umbrella organisation "Norden Associations Federal" (Föreningarna Nordens Förbund, FNF), in $1965 .{ }^{49}$ This new kind of organisational basis for the associations was

48 Foreningene Nordens kongress, Oslo 1-2 juli 1954 (Oslo: Foreningen Norden, 1955), 7-8.

49 Jan A. Andersson, Idé och verklighet: Föreningarna Norden genom 70 år (Stockholm: Föreningen Norden, 1991), 91. 
in a way forced by the new debates on international cooperation in the post-war era. This could be considered a less nationally territorialised conceptualisation of Nordic cooperation. Further evidence of this was some new regional activities initiated by the associations, for example in the Cap of the North, especially in the Torne Valley, and the Norden Associations were engaged in the conferences held both in Northern Sweden and Finland, and in western Sweden and eastern Norway, regarding cooperation on the local level between municipalities on both sides of the border. ${ }^{50}$

This way of conceptualising Norden at the organisational level in the post-war period also had consequences for the associations' ideas about education. At the first Nordic congress in Oslo in 1954, there was a lecture and a debate regarding Nordic languages in Nordic schools. The focus on making sure that pupils learned something about the other Nordic countries and their languages seems to have still been focused upon. ${ }^{51}$ One interesting point that had come up in meetings between the boards of the Norden Associations in the last years of the 1940s was that the syllabi for Nordic languages should be the same in each of the countries. ${ }^{52}$ This further points in the direction of less nationalistic methodical features of the Nordic cooperation in the educational field.

While the revision of history textbooks was on-going, attention was also turned towards geography textbooks. In 1948, the idea-which was forwarded by the Finnish association already in 1938-was discussed in more detail. What was especially problematic for the Nordic interest of the Norden Associations was that the Nordic region was not described as a region in many geography textbooks: "It would be of the utmost importance that the Nordic countries be treated together in one section as a kind of unit, so that it is not so, as currently is the case, that Finland is attributed to Eastern Europe and Denmark to Central Europe." ${ }^{53}$ The commission of experts on geography textbooks did not amass a lot of activity and fell into dormancy in the 1950s after what was described as an intense couple of years between the end of the 1940s and the beginning of the 1950 s. $^{54}$ Still, their activity is especially interesting for what it can say about the negotiation over how Norden was imagined, and could be imagined. The geography discussions are interesting because they not only focused on how the Nordic countries were wrongfully described, but also paid - at least someattention to Nordicness itself and the perceived boundaries of Norden. ${ }^{55}$

Teacher meetings continued to be held, as well as shorter teacher exchanges. In the post-war era students of different ages were also sent on study trips to their neighbouring countries at the expense of the Norden Associations. ${ }^{56}$ During the post-war

50 Ibid., 95.

51 Ibid., 32-56.

52 Ibid., 41.

53 Minutes from the meeting in the Internordic commission of experts regarding geography textbooks, April 19, 1948, vol. 196, ANNA, NNA, \$ 3 (my translation).

54 Letter from Veikko Karsma (the Finnish association) to all Norden Associations, December 8, 1966, vol. 198, ANNA, NNA, 1-3.

55 Minutes from the meeting in the Internordic commission of experts regarding geography textbooks, April 19, 1948, vol. 196, ANNA, NNA, $\$ 3$.

56 For descriptions of activities see e.g. Nordisk tidskrift 1948, 282; Nordisk tidskrift 1951, 80, 281; Nordisk tidskrift 1954, 57-59, 124-25, 270-71; Nordisk tidskrift 1958, 57, 131-33, 340, 417-18, 472; Nordisk tidskrift 1960, 66-68, 493-97. 
era most of the teacher meetings were directed towards teachers of specific subjects such as geography, history, and social studies. These meetings also took a different turn where, for example, the Nordic perspective itself was fought for and "the idea of Nordism" and "international understanding" was specifically addressed. ${ }^{57}$ In the post-war era a lot of attention in many school subjects was directed away from not only the national situation, but also away from the Nordic perspective, and more attention was given to the European and global perspectives. At least that was what the representatives of the associations had seen and they saw it as a problem..$^{58}$ Meanwhile, the school trips directed at students were still focused towards learning about "the other" nationalities, rather than learning about an inclusive Nordic youth. ${ }^{59}$ The methods established in the interwar period were still in effect, even though Nordism had been clearly challenged by a new supranationalistic discourse.

A tendency towards a more "organised Nordism" might be visible in the efforts of the Norden Associations in the wake of World War Two. They were more or less forced to take a more global, or at least European, international stand-with more focus on Norden itself and less on the nations that made up Norden-in order to stay relevant in a world that took a big turn towards supranational cooperation.

The nation was certainly still taken for granted, but on the level of territorialisation there was a small but noticeable shift towards Nordic territorialisation in the post-war era when compared to the interwar era. Still, no common viewpoint was really established, which in part could be a consequence of organisational ignorance. Paradoxically, while the nationalistic spokespersons of the interwar era did not ignore the nation, but in a way actively promoted national solutions to methods of cooperation, the-perhaps-less nationalistic spokespersons and board members of the post-war era did not really see how their inherited methods were imbued with national thought, as a consequence of ignoring the national condition of the societies which they were trying to change.

\section{Conclusion}

During the pre-war era, methods and organising principles for Nordic cooperation were established within a nationalistic logic. Cooperation and the dispersal of Nordistic ideas were established on different levels, from the local to the Nordic. Björn Norlin has also shown that these levels of organisational geographies that set the dispersal of Nordistic ideas in a context of local, regional, national, and Nordic cooperation on seemingly apolitical subjects were also at the centre of the Nordic youth movement in the late nineteenth century and early twentieth century. ${ }^{60} \mathrm{~A}$ lot of the organisational frames for cooperation in the educational arena were established around the nation as the basis, with educational policy becoming more and more national in the late nineteenth century. However, local and regional organisational features were also evident, and these levels set boundaries for Nordic cooperation.

57 See e.g. Nordic study course for teacher students and younger teachers, August 7-13, 1960, vol. 202, ANNA, NNA.

58 See e.g. Preliminary programme for Nordic history teacher course in Sigtuna, August 3-8, 1952, F10A:1, ASNA, SNA; Studyseminar on textbooks on Nordic history at Elingaard, June 30-July 5, 1958, F10A:1, ASNA, SNA.

59 See e.g. Arne F. Andersson, “Vår skolreseverksamhet," Nordens tidning 9 no. 1 (1951), 3-5.

60 Norlin (2014), 101. 
Even if the idea was to disseminate Nordistic ideas, all Nordic endeavours had to rely on national organisations.

For ideological reasons, based in nationalism, the Norden Associations adopted a very nationally framed organisational foundation, with one association for each of the Nordic nations. During the interwar period this really showed in the methods utilised by the Norden Associations within the educational field. The Nordic idea was mostly circulated without any articulated meaning of the word Norden. Instead knowledge about the other Nordic nations was established as the most important method to make the Nordic youth more supportive of the Nordistic cause, without any real manifestation of what the Nordistic cause really was.

During the post-war era, other more internationally oriented supranational organisations (EEC, UN, Council of Europe, etc.) were established, and the Norden Associations followed suit in many respects, for example, by creating the "Norden Associations Federal." The methods linked to education also tended to be more based in ideas of Norden as a whole, for example, by taking a stand for a Nordic perspective at a time when European and global perspectives threatened to wedge Norden out of education, going directly from national to European contexts, and skipping the Nordic countries as a cohesive entity.

I have discussed these changes in relation to some concepts derived from methodological nationalism. The organisation of political power since the French Revolution has on a large scale been connected to the nation and therefore had much of its organisational frames ready to be taken for granted. Nordists might have felt the same about Norden, with preconceptions that, for them, made Norden something that could be taken for granted, but at the same time they obviously knew they had to "sell" the idea of Norden to the public, which was the idea behind utilising educational arenas for the Nordic cause.

By breaking down what comprises methodological nationalism in social research-ignorance, taking for granted, and territorialisation-the concept might lend itself to shed some light upon how organisations like the Norden Associations were able to (or not able to) utilise education to circulate ideas about identities beyond the nation. For example, Norden seems to have never been taken for granted the way the nation was. There was probably (and still is) some sense of what Norden is among the general public in the Nordic countries, but it is not imagined as deeply and profound as the nation. As Benedict Anderson observed, the nation is imagined as both special and universal in that everyone belongs to (or should belong to) a nation, but all nations are also unique in that, for example, the Danish nation is like no other nation. ${ }^{61}$ Not everyone belongs to a regional, semi-supranational entity like Norden, and it needs to be explained, exactly because it is not a nation. Nordism goes out of its way to declare that it consists of independent sovereign nations all having something in common.

It is regarding territorialisation that Nordism might be more easily understood. The "new" territorialisation that consisted of a definition of a geographical region and its relation to other regions was more or less dependent on the concept of "levels." Building from the local and regional levels, where for instance cooperation in regions overlapping national boundaries was supported by the associations, Nordists tried to

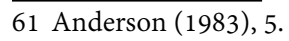


establish an educational Nordic level between the national and the European. This work was especially visible in the post-war era through the associations' work with geography and history textbooks. However, even in this respect there seems to be a conscious tenacity to imagine a new kind of territorialisation, with clear intentions.

There had been clear ideological reasons for making sure Nordic cooperation was based in the supremacy of nations during the interwar period. The organisational structures established in this period were then maintained-mostly through what Wimmer and Glick-Schiller would call ignorance-during the post-war era, when the ideological reasons for upholding a strong nationalist sentiment were weakened, in favour of Nordic territorialisation. The establishment of a Nordic sentiment was effectively hindered by organisational structures based in a perceived natural principality of nations, which ultimately trumped any transnational idea.

In short, Norden was not taken for granted, the way the nations were, and while there was a tendency to try to territorialise Norden, these efforts were accompanied by ignoring the national condition of the Nordic countries, and the national condition of the cooperation itself. By not exploring this national condition, and what it might mean for Nordism, the Norden Associations continued to re-enact national frames, not least in the way they organised their educational efforts. 


\section{References}

\section{Archival sources}

Swedish National Archives (Riksarkivet, SNA)

Archive of the Swedish Norden Association (Föreningen Nordens arkiv, ASNA)

A1; A4; F10A:1-9.

Norwegian National Archives (Riksarkivet, NNA)

Archive of the Norwegian Norden Association (Foreningen Nordens arkiv, ANNA) Volume 193-200.

\section{Printed sources}

Andersson, Arne F. "Vår skolreseverksamhet." Nordens tidning 9, no. 1 (1951), 3-5

Föreningen Norden och det nordiska samarbetet. Stockholm: Föreningen Norden, 1928.

Foreningene Nordens kongress, Oslo 1-2 juli 1954. Oslo: Foreningen Norden, 1955.

Norden: Förening i Finland för nordiskt samarbete 1924-1934.

Nordens kalender 1934.

Nordens kalender 1936.

Nordisk tidskrift 1948-1960.

\section{Literature}

Åkerlund, Andreas, "Ambassadors of the Swedish Nation: National Images in the Teaching of the Swedish Lecturers in Germany 1918-1945." Paedagogica Historica 51, no. 5 (2015), 595-613.

Andersson, Benedict. Imagined Communities: Reflections on the Origin and Spread of Nationalism. London: Verso, 1983.

Andersson, Håkan. "Skola och lärare i nordismens tjänst: De nordiska skolmötena 1870-1910." In Utbildningshistoria 1989, edited by Urban Dahlöf. Årsböcker i svensk undervisningshistoria 163. Uppsala: Föreningen för svensk undervisningshistoria, 1989.

Andersson, Jan A. Idé och verklighet: Föreningarna Norden genom 70 år. Stockholm: Föreningen Norden, 1991.

Andersson, Jan A. Nordiskt samarbete: Aktörer, idéer och organisering 1919-1953. Lund: Lund University, 1994.

Backholm, Johan. "När lärarna blev nordister: Om skandinavism och nordism på de första nordiska skolmötena." Nordisk tidskrift no. 6 (1994).

Beck, Ulrich. "The Cosmopolitan Society and its Enemies." Theory, Culture \& Society 19, no. 1-2 (2002).

Berggren, Henrik. Seklets ungdom: Retorik, politik och modernitet 1900-1939. Stockholm: Tidens förlag 1995.

Billig, Michael. Banal Nationalism. London: Routledge, 1995.

Boli, John and George M. Thomas. "INGOs and the Organization of World Culture," in Constructing World Culture: International Non-Governmental Organizations since 1875, edited by John Boli and George M. Thomas. Palo Alto: Stanford University Press, 1999.

Browning, Christopher S. and Pertti Joenniemi, "From Fratricide to Security Community: Re-Theorising Difference in the Constitution of Nordic Peace." Journal of International Relations and Development 16 (2013), 483-513. 
Cooper, Sandi E. Patriotic Pacifism: Waging War on War in Europe, 1815-1914. New York: Oxford University, 1991.

Duedahl, Poul. "Selling Mankind: UNESCO and the Invention of Global History." Journal of World History 22, no. 1 (2011).

Elliott, B. J. "The League of Nations Union and History Teaching in England: A Study in Benevolent Bias." History of Education 6, no. 2 (1977).

Elmersjö, Henrik Åström. Norden, nationen och historien: Perspektiv på föreningarna Nordens historieläroboksrevision 1919-1972. Lund: Nordic Academic Press, 2013.

Elmersjö, Henrik Åström. “The Norden Associations and International Efforts to Change History Education, 1919-1970: International Organisations, Education, and Hegemonic Nationalism.” Paedagogica Historica 51, no. 6 (2015).

Elmersjö, Henrik Åström. "Negotiating Norden: Nordic Historians Revising History Textbooks, 1920-1970." In Making Nordic Historiography: Connections, Tensions \& Methodology, 1850-1970, edited by Pertti Haapala, Marja Jalava and Simon Larsson. New York: Berghahn Books, 2017.

Engman, Max. “Är Finland ett nordiskt land?” Den jyske Historiker 69-70 (1994).

Engman, Max and Åke Sandström. "Det nya Norden.” In Det nya Norden efter Napoleon, edited by Max Engman and Åke Sandström. Stockholm: Stockholm University, 2004.

Faure, Romain. Netzwerke der Kulturdiplomatie: Die Internationale Schulbuchrevision in Europa, 1945-1989. Berlin: Walter de Gruyter, 2015.

Fuchs, Eckhardt. "Educational Sciences, Morality and Politics: International Educational Congresses in the Early Twentieth Century." Paedagogica Historica 40, no. 5-6, (2004), 757-84.

Fuchs, Eckhardt. "The Creation of New International Networks in Education: The League of Nations and Educational Organizations in the 1920s." Paedagogica Historica 43, no. 2 (2007), 199-209.

Haarder Ekman, Kari. "Mitt hems gränser vidgades:” En studie i den kulturella skandinavismen under 1800-talet. Göteborg: Makadam, 2010.

Hansen, Svein Olav. "Foreningerne Norden 1919-1994: Ambisjoner og virklighet." Den jyske Historiker 69-70 (1994).

Hecker-Stampehl, Jan. Vereinigte Staaten des Nordens: Integrationsideen in Nordeuropa im Zweiten Weltkrieg. München: Oldenburg, 2011.

Hemstad, Ruth. Fra Indian Summer til nordisk vinter: Skandinavisk samarbeid, skandinavisme og unionsuppløsningen. Oslo: Akademisk publicering, 2008.

Hovbakke Sørensen, Lars. "Norden som idé og praksis: Den danske Foreningen Nordens rolle som politisk-ideologisk pressionsgruppe 1940-1960." Historie, no. 1 (1996).

Iriye, Akira. Global Community: The Role of International Organizations in the Making of the Contemporary World. Berkeley: University of California Press, 2002.

Janfelt, Monika. "Föreningarna Norden mellan nordism och nationalism.” In Mångkulturalitet och folkligt samarbete, edited by Krister Ståhlberg, Nord 2000:29, 15-33. Copenhagen: Nordisk Ministerråd, 2000.

Janfelt, Monika. Att leva i den bästa av världar: Föreningarna Nordens syn på Norden 1919-1933. Stockholm: Carlssons, 2004.

Kayser Nielsen, Nils. Bonde, stat og hjem: Nordisk demokrati og nationalism - fra pietismen til 2. verdenskrig. Aarhus: Aarhus universitetsforlag, 2009. 
Kolasa, Jan. International Intellectual Cooperation: The League Experience and the Beginnings of UNESCO. Wrocław: Polskiej Akademii, 1962.

Landahl, Joakim. "Det nordiska skolmötet som utbildningspolitisk arena (18701970): Ett rumsligt perspektiv på den moderna pedagogikens historia.” Utbildning \& Demokrati 24, no. 3 (2015), 7-23.

Manela, Erez. The Wilsonian Moment: Self-Determination and the International Origins of Anticolonial Nationalism. Oxford: Oxford University Press, 2007.

Marklund, Carl. "A Swedish Norden or a Nordic Sweden? Image Politics in the West during the Cold War." In Communicating the North: Media Structures and Images in the Making of the Nordic Region, edited by Jonas Harvard and Peter Stadius. New York: Routledge, 2013.

Martins, Herminio. "Time and Theory in Sociology." In Approaches to Sociology: An Introduction to Major Trends in British Sociology, edited by John Rex. London: Routledge, 1974.

Nilsson, Ingela. Nationalism i fredens tjänst: Svenska skolornas fredsförening, fredsfostran och historieundervisning 1919-1939. Umeå: Umeå University, 2015.

Norlin, Björn. “The Nordic Secondary School Youth Movement: Pupil Exchange in the Era of Educational Modernization, 1870-1914." In Beyond the Classroom: Studies on Pupils and Informal Schooling Processes in Modern Europe, edited by Anna Larsson and Björn Norlin, 83-102. Frankfurt am Main: Peter Lang, 2014.

Norman, Torbjörn. "Ansiktet mot öster: Svensk nationalism mot Nationernas förbund.” In Väst möter Öst: Norden och Ryssland genom historien, edited by Max Engman. Stockholm: Carlssons, 1996.

Nygren, Thomas. "UNESCO and Council of Europe Guidelines, and History Education in Sweden, c. 1960-2002." Education Inquiry 2, no. 1 (2011).

Østergaard, Uffe. “Norden - europæisk eller nordisk?” Den jyske Historiker 69-70 (1994).

Østergaard, Uffe. “The Geopolitics of Nordic Identity: From Composite States to Nation States." In The Cultural Construction of Norden, edited by Øystein Sørensen and Bo Stråth. Oslo: Scandinavian University Press, 1997.

Østergaard, Uffe. “The History of Europe Seen from the North." European Review 14, no 2 (2006).

Roos, Merethe. "Tidlige skoleforbindelser: Svensk-norsk idéutveksling på skolens område rundt midten av det 19. århundre og dannelsen av tekstkulturer over kjølen." Nordic Journal of Educational History 5, no. 1 (2018).

Siegel, Mona. The Moral Disarmament of France: Education, Pacifism, and Patriotism, 1919-1940. New York: Cambridge University Press, 2004.

Smith, Anthony D. Nationalism in the Twentieth Century. Oxford: Martin Robertson, 1979.

Sørensen, Øystein and Bo Stråth. "Introduction: The Cultural Construction of Norden." In The Cultural Construction of Norden, edited by Øystein Sørensen and Bo Stråth. Oslo: Scandinavian University Press, 1997.

Stadius, Peter. "Happy Countries: Appraisals of Interwar Nordic Societies.” In Communicating the North: Media Structures and Images in the Making of the Nordic Region, edited by Jonas Harvard and Peter Stadius. New York: Routledge, 2013.

Stenius, Henrik. "Nordic Associational Life in a European and an Inter-Nordic Perspective." In Nordic Associations in a European Perspective, edited by Risto Alapuro and Henrik Stenius, 29-88. Baden-Baden: Nomos, 2010. 
Stråth, Bo. "The Swedish Image of Europe as the Other." In Europe and the Other and Europe as the Other, edited by Bo Stråth. Brussels: Peter Lang, 2000.

Wåhlin, Vagn. "Island, Færøerne, Grønland og det nordiske." Den jyske Historiker 69-70 (1994).

Wimmer, Andreas and Nina Glick Schiller. "Methodological Nationalism and Beyond: Nation-state Building, Migration, and the Social Sciences." Global Networks 2, no. 4 (2002).

Wright, Susannah. "Creating Liberal-Internationalists World Citizens: League of Nations Union Junior Branches in English Secondary Schools, 1919-1939." Paedagogica Historica 56, no. 3 (2020). 